Tropical Journal of Pharmaceutical Research May 2021; 20 (5): 995-1002

ISSN: $1596-5996$ (print); 1596-9827 (electronic)

(C) Pharmacotherapy Group, Faculty of Pharmacy, University of Benin, Benin City, 300001 Nigeria.

Original Research Article

http://dx.doi.org/10.4314/tjpr.v20i5.16

\title{
Fertility-enhancing potential of ethanol extract of Cuscuta chinensis seeds in a rat model of unilateral cryptorchidism
}

\author{
Jiao Shu' ${ }^{1}$, Li Li ${ }^{2}$, Hui Yu ${ }^{1}$, Dandan Zhang ${ }^{1 *}$ \\ ${ }^{1}$ Department of Reproductive Medicine, ${ }^{2}$ Department of Science and Education, Puren Hospital Affiliated to Wuhan University \\ of Science and Technology, Wuhan City, Hubei Province 430081, China \\ *For correspondence: Email: dandanzhang31@yahoo.com; Tel/Fax: 0086-02786857375/027-86360020
}

\begin{abstract}
Purpose: To investigate the fertility-enhancing potential of the ethanol extract of Cuscuta chinensis seeds in a rat model of unilateral cryptorchidism (ULC), and the mechanism(s) of action.

Methods: Healthy male Sprague Dawley rats $(n=48$; mean weight $=220 \pm 10 \mathrm{~g}$ ) were randomly assigned to 4 groups (12 rats/group): control, ULC, $100 \mathrm{mg}$ extract/kg and $200 \mathrm{mg}$ extract/kg groups. Unilateral cryptorchidism of right testis was induced via standard method using an operating microscope. Rats in the treatment groups received 100 and $200 \mathrm{mg}$ of ethanol extract of Cuscuta chinensis/kg orally once a day for 60 days. Sperm count and sperm motility were determined in seminal vesicular fluid (SVF) suspension. Oxidative stress markers and histological changes in rat testis were evaluated. The levels of caspase-3 and caspase-9 in testicular tissue were assessed by enzyme-linked immunosorbent assay (ELISA), while the protein expressions of Nrf2 and heme oxygenase 1 (HO-1) were determined using Western blotting.

Results: Body and reproductive organ weights, sperm count, sperm motility, and activities of glutathione peroxidase (GPX), catalase and superoxide dismutase (SOD) were significantly reduced in ULC group, relative to control group, but these parameters were significantly and dose-dependently increased following extract treatment $(p<0.05)$. Malondialdehyde $(M D A)$, 8-hydroxy-2'-deoxyguanosine (8-OHdG), caspase-3 and caspase-9 levels were significantly higher in ULC group than in control group, but they were reduced significantly and dose-dependently after extract treatment $(p<0.05)$. Moreover, the protein expressions of Nrf2 and HO-1 were significantly downregulated in ULC group, when compared with control group, but they were significantly and dose-dependently upregulated by the extract $(p<0.05)$. Cross sections of testicular tissues of rats in ULC group revealed narrowed and thickened seminiferous tubules (disrupted spermatogonia) characterized by increased apoptotic bodies (increased number of necrotic Sertoli and Leydig cells). However, there were few damaged or necrotic Sertoli and Leydig cells, and complete absence of thickening of seminiferous tubules in testicular tissues of rats treated with the extract.

Conclusion: The ethanol extract of Cuscuta chinensis seeds effectively mitigates cryptorchidism in rats via mechanisms involving the regulation of Nrf2/HO-1 signaling pathway, and inhibition of apoptosis and oxidative stress. Thus, the plant extract has potentials for further development for the management of male infertility
\end{abstract}

Keywords: Cuscuta chinensis, Cryptorchidism, Apoptosis, Antioxidant enzymes, Sperm motility, Testis

This is an Open Access article that uses a fund-ing model which does not charge readers or their institutions for access and distributed under the terms of the Creative Commons Attribution License (http://creativecommons.org/licenses/by/4.0) and the Budapest Open Access Initiative (http://www.budapestopenaccessinitiative.org/read), which permit unrestricted use, distribution, and reproduction in any medium, provided the original work is properly credited.

Tropical Journal of Pharmaceutical Research is indexed by Science Citation Index (SciSearch), Scopus, International Pharmaceutical Abstract, Chemical Abstracts, Embase, Index Copernicus, EBSCO, African Index Medicus, JournalSeek, Journal Citation Reports/Science Edition, Directory of Open Access Journals (DOAJ), African Journal Online, Bioline International, Open-J-Gate and Pharmacy Abstracts 


\section{INTRODUCTION}

Inability to conceive after one year of unprotected sexual intercourse (infertility) results in low birth rate. Infertility is a major global issue which impacts negatively on patients and their family members [1]. In China, the prevalence of infertility among newly married couples ranges from 8 - $13.6 \%$ [2]. Cryptorchidism or undescended testis (a birth defect), genetic disorders (hormonal imbalance/insufficiency), infection, duct obstruction, varicocele, excessive alcohol consumption, and smoking are important factors that contribute to male infertility $[3,4]$. Surgically-induced cryptorchidism reversibly damages seminiferous epithelium/tubules (germ cells) via induction of oxidative stress and apoptosis, thereby adversely affecting spermatogenesis [5]. Animal model of cryptorchidism remains the best model for assessment of clinical effectiveness of synthetic and natural aphrodisiac drugs [6,7]. Studies have shown that supplementation with antioxidants significantly improve overall sperm quality, thereby enhancing fertility $[4,8,9]$. Cuscuta chinensis Lam. (Chinese Dodder/Tu-Si-Zi), a parasitic plant belonging to the Convolvulaceae family, is used in Traditional Chinese Medicine (TCM) as an analgesic, and for improving sexual, liver and kidney functions [10]. The plant seeds exhibit a broad spectrum of pharmacological properties such as antioxidant, anti-inflammatory, anti-aging, anti-depressant, and anticancer effects [11-13]. Administration of herbal formulation rich in Cuscuta chinensis (KH-204) has been shown to significantly reduce the levels of oxidative stress, heat shock proteins, and germ cell apoptosis, while improving sexual function [14]. Flavones isolated from Cuscuta chinensis seeds significantly increased testosterone and protein levels in a mouse model of infertility [15]. Similarly, Cuscuta chinensis flavonoids have been reported to significantly improve sperm count and sperm motility in mice [16]. This study investigated the fertilityenhancing effect of ethanol extract of Cuscuta chinensis seeds on rat model of ULC.

\section{EXPERIMENTAL}

\section{Materials}

Glutathione peroxidase (GPx), catalase, SOD and MDA assay kits were products of Sangon Biotechnology (China). Light microscope (E50) was bought from Olympus Co. Ltd. (Japan). Phenol-free DNeasy tissue kit was purchased from Qiagen (USA) and 8-OHgdG ELISA kit was product of Abcam (UK). Caspase-3 and caspase9 ELISA kits were obtained from Beyotime
Biotech (China). Nuclear/cytosolic fractionation kit was bought from Cell Biolabs Inc. (USA). Primary antibodies for Nrf2, $\mathrm{HO}-1$, histone $\mathrm{H} 3$ and $\beta$-actin were products of Santa Cruz Biotechnology (USA). Enhanced chemiluminescence (ECL) detection system was purchased from Bio-Rad Laboratories (USA). Horseradish peroxidase (HRP) anti-rabbit IgG antibody was bought from Cell Signaling Technology (USA), while image analyzing software was obtained from Amersham Pharmacia Biotech (UK).

\section{Preparation of ethanol extract of Cuscuta chinensis seeds}

The seeds of Cuscuta chinensis Lam. were obtained from a traditional Chinese drug store in Wuhan, China, and authenticated by Dr. Chang Wang of the Department of Botany, Wuhan University. A herbarium specimen (voucher no. DCWU-12/53/2010) was prepared and deposited in the herbarium of the Department of Botany, Wuhan University. The plant seeds were shadedried and pulverized using an electric blender. Extraction was done using standard methods [17]. A portion of the powder $(500 \mathrm{~g})$ was exhaustively extracted with $1000 \mathrm{~mL}$ of $95 \%$ ethanol in a Soxhlet apparatus. The extract was concentrated using a vacuum rotatory evaporator, and the resultant concentrate was freeze-dried by lyophilization. The dried ethanol extract $(7.44 \%, w / w)$ was stored at $-20^{\circ} \mathrm{C}$ prior to use.

\section{Determination of total phenolic and flavonoid contents of the extract}

Total phenolic and flavonoid contents of ethanol extract of Cuscuta chinensis seeds were determined using previously described methods $[18,19]$. Total phenolic content was expressed as $\mathrm{mg}$ gallic acid equivalent (GAE)/g dry extract, while flavonoid content was expressed as $\mathrm{mg}$ quercetin equivalent $(\mathrm{QE}) / \mathrm{g}$ dry extract.

\section{Experimental rats}

Healthy male Sprague Dawley rats $(n=48)$ weighing $210-230 \mathrm{~g}$ (mean weight $=220 \pm 10$ g) were purchased from Wuhan University of Science and Technology. The rats were housed in polycarbonate cages under standard conditions and allowed free access to standard feed (rat chow) and water. They were exposed to 12-h light/12-h dark cycle, and maintained at an average temperature of $22 \pm 1{ }^{\circ} \mathrm{C}$ and $40-50 \%$ humidity. The rats were acclimatized to the laboratory conditions for 10 days before commencement of study. The study protocol was 
approved by the Institutional Animal Ethics Committee of Wuhan University of Science and Technology (approval no. WU-21-AE20). The study procedures were carried out in strict adherence to the Guide for Care and Use of Laboratory Animals, National Academic Press (USA).

\section{Animal grouping and treatments}

After the acclimatization period, the rats were randomly assigned to 4 groups (12 rats/group): control, ULC, $100 \mathrm{mg}$ extract/kg and $200 \mathrm{mg}$ extract/kg groups. Unilateral cryptorchidism of right testis was induced via standard method using an operating microscope [20]. The rats were anesthetized with intraperitoneal injection (i.p) of sodium pentobarbital at a single dose of $45 \mathrm{mg} / \mathrm{kg}$ after which inguinal incision of $2 \mathrm{~cm}$ was made on the right testis of each rat to reveal the spermatic cord. The testis was slowly retracted to the posterior abdominal wall and sutured with $4 / 0$ nylon to the tunical albuginea to prevent its movement back to the scrotal sac. Rats in the treatment groups received 100 and $200 \mathrm{mg}$ of ethanol extract of Cuscuta chinensis $/ \mathrm{kg}$ orally once a day for 60 days.

\section{Tissue sample preparation}

At the end of the treatment period (on the $61^{\text {st }}$ day), the rats were weighed and euthanized via cervical dislocation under mild ethyl ether anesthesia $(20 \mathrm{mg} / \mathrm{kg})$. Both testicle, cauda epididymis, and seminal vesicles were immediately excised, washed with phosphatebuffered saline (PBS) and weighed. A portion of excised testis was homogenized with PBS to prepare $10 \%$ tissue homogenate which was centrifuged at $3000 \mathrm{rpm}$ for $10 \mathrm{~min}$ at $4{ }^{\circ} \mathrm{C}$. Biochemical analyses were performed on the supernatant.

\section{Semen analysis}

The distal end of caudal epididymis was minced with physiological saline and shaken vigorously on an agitator at $37^{\circ} \mathrm{C}$ for $15 \mathrm{~min}$ to separate sperm/spermatozoa suspension from SVF. Sperm count and sperm motility were determined using SVF suspension [21]. Sperm count was expressed as millions/mL of SVF suspension, while sperm motility calculated as percentage of motile sperms in total sperm count.

\section{Measurement of oxidative status in rat testis}

The activities of GPx, catalase, and SOD, and levels of testicular MDA were determined using their assay kits.

\section{Determination of 8-OHdG levels}

Deoxyribonucleic acid (DNA) was extracted from SVF using phenol-free DNeasy tissue kit and then digested. The level of $8-\mathrm{OHgdG}$ in the digest was determined with ELISA.

\section{Determination of testicular cell apoptosis}

The activities of caspase- 3 and caspase- 9 in testicular tissue homogenate were assayed using their respective ELISA kits.

\section{Western blotting}

Cytosolic and nuclear fractions of testicular tissue homogenate were lysed with ice-cold radio-immunoprecipitation assay (RIPA) buffer containing protease and phosphatase inhibitors (PMSF). The resultant lysate was centrifuged at $15,000 \mathrm{rpm}$ for $15 \mathrm{~min}$ at $4{ }^{\circ} \mathrm{C}$, and the protein concentration of the supernatant was determined using bicinchoninic acid (BCA) protein assay kit. A portion of total cell protein $(50 \mu \mathrm{g})$ from each sample was separated on $12 \%$ sodium dodecyl sulphate (SDS)-polyacrylamide gel electrophoresis and transferred to a fixed polyvinylidene difluoride membrane at $110 \mathrm{~V}$ and $90^{\circ} \mathrm{C}$ for $2 \mathrm{~h}$. Subsequently, the membrane was incubated with non-fat milk solution (5\%) in Trisbuffered saline containing $0.2 \%$ Tween-20 (TBS$\mathrm{T})$, with gentle shaking at $37^{\circ} \mathrm{C}$ to block nonspecific binding of the blot. Thereafter, the blots were incubated overnight at $4{ }^{\circ} \mathrm{C}$ with primary antibodies for Nrf2, $\mathrm{HO}-1$, histone $\mathrm{H} 3$ and $\beta$ actin, each at a dilution of 1 to 1000 . Then, the membrane was washed thrice with TBS-T, and further incubated with horseradish peroxidaseconjugated goat anti-rabbit IgG secondary antibody for $45 \mathrm{~min}$ at room temperature. The blot was developed using Enhanced Chemiluminescence (ECL) detection system. Grayscale analysis of the bands was performed using ImageJ Launcher software. The respective protein expression levels were normalized to that of $\beta$-actin which served as standard.

\section{Histopathological examination of rat testis}

A portion of decapsulated testis (right) was fixed in $10 \%$ formaldehyde. The formaldehyde-fixed testicular tissue was washed in water to remove excess fixative and then dehydrated using graded concentrations of ethyl alcohol. It was then cleared with xylene, and thereafter embedded in paraffin. Tissue sections (5- $\mu \mathrm{m}$ thick) were made using an ultra-microtome. The sections were stained with hematoxylin and eosin (H\&E) for $12 \mathrm{~h}$ at room temperature according to standard methods, and examined 
under a light microscope. Morphological changes in rat testis were recorded and analyzed with ImageJ analysis software.

\section{Statistical analysis}

Data are expressed as mean \pm SEM. Statistical analysis was performed with SPSS version 20 . Groups were compared using Dunnett's multiple comparison test. Values of $p<0.05$ were taken as indicative of statistically significant differences.

\section{RESULTS}

Total phenolic and flavonoid contents of ethanol extract of Cuscuta chinensis seeds

The results of quantitative phytochemical screening showed that total phenolic content of the extract was significantly higher than the total flavonoid content $(p<0.05$; Table 1$)$.

\section{Effect of extract treatment on body and organ weights}

As shown in Table 2, body and reproductive organ (testis, seminal vesicle and epididymis) weights were significantly reduced by ULC, but they were significantly and dose-dependently
Table 1: Phytochemical profile of Cuscuta chinensis seeds

\begin{tabular}{ll}
\hline Phytochemical & Concentration \\
\hline Total phenols & $48.10 \mathrm{mg} \mathrm{GAE} / \mathrm{g}$ \\
Total flavonoids & $24.20 \mathrm{mg} \mathrm{QE} / \mathrm{g}$ \\
\hline
\end{tabular}

increased by ethanol extract of Cuscuta chinensis seeds $(p<0.05)$.

\section{Effect of extract treatment on sperm quality}

Sperm count and sperm motility were significantly lower in ULC group than in control group, but these parameters were significantly and dose-dependently increased by extract treatment $(p<0.05)$. These results are shown in Table 3.

\section{Effect of extract treatment on testicular oxidative status}

The activities of GPx, catalase and SOD were reduced in ULC group, relative to control group, but they were significantly and dose-dependently increased by extract treatment $(p<0.05$; Table 4). Malondialdehyde (MDA) and 8-OHdG levels were significantly higher in ULC group than in control group, but they were markedly and dosedependently reduced by ethanol extract of Cuscuta chinensis seeds ( $p<0.05$; Figure 1).

Table 2: Changes in body and reproductive organ weights

\begin{tabular}{lcccc}
\hline Group & $\begin{array}{c}\text { Change in body } \\
\text { weight }(\mathbf{g})\end{array}$ & Testis weight(g) & $\begin{array}{c}\text { Seminal vesicle } \\
\text { weight }(\mathbf{g})\end{array}$ & $\begin{array}{c}\text { Epididymis weight } \\
(\mathbf{g})\end{array}$ \\
\hline Control & $42.23 \pm 2.60$ & $1.87 \pm 0.10$ & $0.43 \pm 0.03$ & $0.45 \pm 0.04$ \\
ULC & $36.20 \pm 1.72^{\mathrm{a}}$ & $1.34 \pm 0.08^{\mathrm{a}}$ & $0.30 \pm 0.02^{\mathrm{a}}$ & $0.28 \pm 0.03^{\mathrm{a}}$ \\
Extract $(100 \mathrm{mg} / \mathrm{kg})$ & $38.30 \pm 1.80^{\mathrm{b}}$ & $1.55 \pm 0.15^{\mathrm{b}}$ & $0.35 \pm 0.04^{\mathrm{b}}$ & $0.35 \pm 0.04^{\mathrm{b}}$ \\
Extract $(200 \mathrm{mg} / \mathrm{kg})$ & $39.70 \pm 2.05^{\mathrm{b}}$ & $1.68 \pm 0.10^{\mathrm{b}}$ & $0.39 \pm 0.03^{\mathrm{b}}$ & $0.41 \pm 0.05^{\mathrm{b}}$ \\
\hline
\end{tabular}

${ }^{\mathrm{a} P} P<0.05$ compared with control group; ${ }^{\mathrm{b}} p<0.05$ compared with ULC group

Table 3: Changes in sperm quality

\begin{tabular}{lcc}
\hline Group & $\begin{array}{c}\text { Sperm count } \\
\text { (million } / \mathrm{mL})\end{array}$ & Sperm motility (\%) \\
\hline Control & $80.92 \pm 7.44$ & $81.56 \pm 9.73$ \\
ULC & $52.75 \pm 5.82^{\mathrm{a}}$ & $56.52 \pm 5.33^{\mathrm{a}}$ \\
Extract $(100 \mathrm{mg} / \mathrm{kg})$ & $65.21 \pm 4.03^{\mathrm{b}}$ & $70.69 \pm 8.28^{\mathrm{b}}$ \\
Extract $(200 \mathrm{mg} / \mathrm{kg})$ & $73.55 \pm 7.35^{\mathrm{b}}$ & $75.55 \pm 9.44^{\mathrm{b}}$ \\
\hline${ }^{\mathrm{a} P}<0.05$, compared with control group; ${ }^{\mathrm{b}} p<0.05$, compared $^{\mathrm{b}}$ with ULC group
\end{tabular}

Table 4: Oxidative status of the treatment groups

\begin{tabular}{lccc}
\hline Group & GPx $(\boldsymbol{\mu g} / \mathbf{m g}$ protein) & Catalase (U/mg protein) & SOD (U/mg protein) \\
\hline Control & $8.12 \pm 1.00$ & $14.10 \pm 1.80$ & $6.27 \pm 1.10$ \\
ULC & $5.08 \pm 0.44^{\mathrm{a}}$ & $10.52 \pm 1.63^{\mathrm{a}}$ & $4.04 \pm 0.82^{\mathrm{a}}$ \\
Extract $(100 \mathrm{mg} / \mathrm{kg})$ & $6.65 \pm 0.82^{\mathrm{b}}$ & $12.20 \pm 1.11^{\mathrm{b}}$ & $4.97 \pm 0.60^{\mathrm{b}}$ \\
Extract $(200 \mathrm{mg} / \mathrm{kg})$ & $7.30 \pm 0.92^{\mathrm{b}}$ & $13.09 \pm 1.58^{\mathrm{b}}$ & $5.40 \pm 0.75^{\mathrm{b}}$ \\
\hline
\end{tabular}

a $P<0.05$, compared with control group; ${ }^{\mathrm{b}} p<0.05$, compared with ULC group. One unit (U) of catalase activity was defined as the amount of enzyme required to decompose $1 \mu \mathrm{mol}$ of $\mathrm{H}_{2} \mathrm{O}_{2}$ per min. One unit of SOD activity was equivalent to the amount of enzyme required for $50 \%$ inhibition of xanthine oxidase 

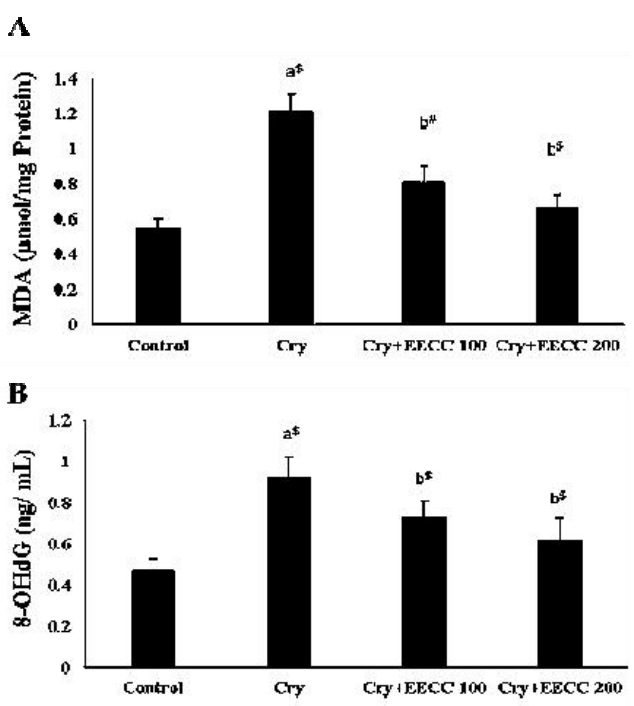

Figure 1: Levels of MDA and $8-O H d G$ in rats. (A): Levels of MDA; (B): Levels of 8-OHdG. ${ }^{a} P<0.05$, compared with control group; ${ }^{b} p<0.05$, compared with ULC group

\section{Effect of extract on the protein expressions of apoptosis-related genes}

As shown in Figure 2, the levels of caspase-3 and caspase- 9 were significantly higher in ULC group than in control group, but they were reduced significantly and dose-dependently by extract treatment $(p<0.05)$.
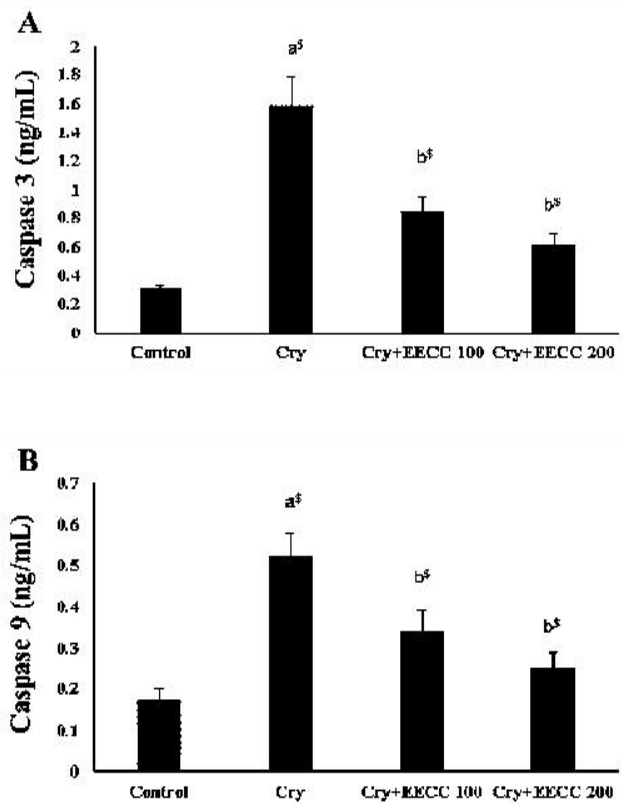

Figure 2: Effect of extract on testicular cell apoptosis. (A): Caspase-3 levels; and (B): Levels of caspase-9. ${ }^{a} P<0.05$, compared with control group; ${ }^{b} p<0.05$, compared with ULC group
Effect of extract treatment on expression levels of Nrf2 and HO-1

The protein expressions of Nrf2 and $\mathrm{HO}-1$ were significantly downregulated in ULC group, when compared with control group, but they were significantly and dose-dependently upregulated by ethanol extract of Cuscuta chinensis seeds ( $p$ $<0.05$; Figure 3).

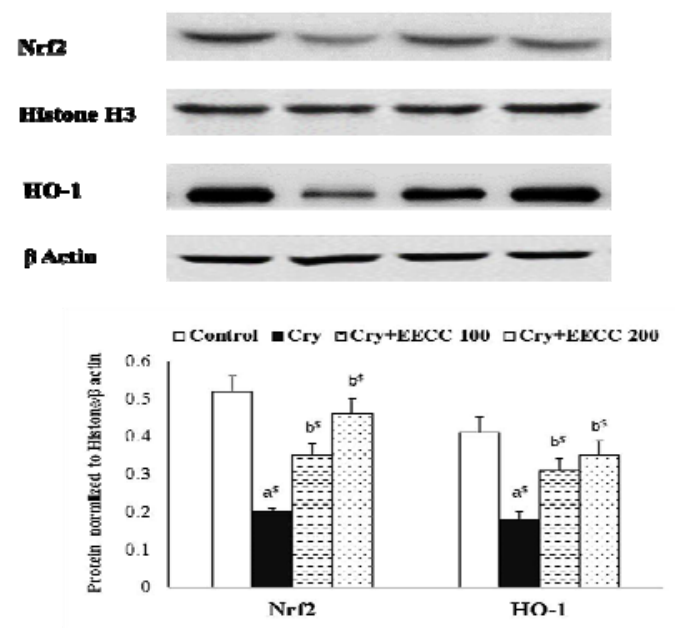

Figure 3: Protein expressions of Nrf2 and $\mathrm{HO}-1$ in rat testis. ${ }^{a} P<0.05$, compared with control group; ${ }^{b} p<$ 0.05 , compared with ULC group

\section{Morphological changes in rat testis}

The results of H\&E staining showed that rats in control group exhibited normal histology of testicular tissue. Cross section of testicular tissues of rats in ULC group revealed narrowed and thickened seminiferous tubules (disrupted spermatogonia) characterized by increased apoptotic bodies (increased number of necrotic Sertoli and Leydig cells). Testicular tissues of rats treated with $100 \mathrm{mg}$ extract $/ \mathrm{kg}$ bwt showed less thickening of seminiferous tubules and reduced number of apoptotic bodies. There were few damaged or necrotic Sertoli and Leydig cells and complete absence of thickening of seminiferous tubules in testicular tissues of rats treated with $200 \mathrm{mg}$ extract $/ \mathrm{kg}$ bwt. These results are shown in Figure 4.

\section{DISCUSSION}

Cryptorchidism, a common birth defect in males, is caused by the failure of testis to descend from the abdominal region to the scrotal sac [7]. Unilateral or bilateral cryptorchidism accounts for $4-8 \%$ of all known cases of male infertility. A strong correlation exists between the incidence of cryptorchidism and testicular cancer [22]. 

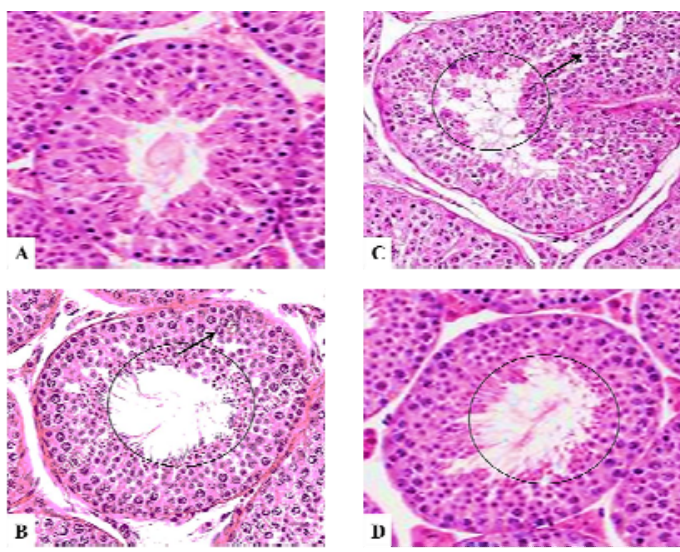

Figure 4: Histopathological features of rat testis. (A): $H \& E$ staining of testicular tissues of rats in control group; (B): results of H\&E staining of testicular tissues of rats in ULC group; (C): results of histopathological examination of testicular tissues of rats treated with $100 \mathrm{mg}$ extract $/ \mathrm{kg}$; and (D): results of histopathological examination of testicular tissues of rats treated with $200 \mathrm{mg}$ extract $/ \mathrm{kg}$

At present, there is need for novel and effective anti-cryptorchidism drugs. This study investigated the aphrodisiac effect of ethanol extract of Cuscuta chinensis seeds on a rat model of infertility. Two doses were chosen based on results of preliminary dose-response study. Cryptorchidism was induced only in the right testis, thereby allowing the left testis to produce normal levels of sex hormone and spermatozoa.

The results showed that body and reproductive organ weights were markedly reduced in ULC group, relative to the control group. However, extract treatment for 60 days significantly increased the body and reproductive organ weights in a dose-dependent fashion. These results suggest that ethanol extract of Cuscuta chinensis seeds may effectively ameliorate ULCinduced testicular damage in rats. The effect of the crude drug may not be unconnected with its antioxidant and anti-apoptotic properties [11,12]. Quantitative phytochemical analysis revealed the presence of high amounts of phenolics and flavonoids in ethanol extract of Cuscuta chinensis seeds. Similarly, High Performance Liquid Chromatography (HPLC) revealed the presence of quercetin, hyperoside and kaempferol in the extract (data not shown).

In cryptorchidism rats, sperm count and sperm motility were significantly reduced, but treatment with graded doses of the extract significantly enhanced the sperm quality, as indicated by increased sperm count and sperm motility. Reduction in sperm quality and secretion of sex hormones are thought to be caused by negative response of the hypothalamus-pituitary axis (HPA). Studies have shown that flavonoids isolated from Cuscuta chinensis seeds enhanced the secretion of endocrine hormones (estrogenic effect) via stimulation of HPA $[16,23]$. In this study, the effect of ethanol extract of Cuscuta chinensis seeds on sperm quality, secretion of sex hormones (testosterone and luteinizing hormone) and spermatogenesis could have occurred via stimulation of HPA.

Sperm cell membrane is rich in polyunsaturated fatty acids (PUFAs), phospholipids (PLs) and mitochondria, making it highly susceptible to oxidative stress-induced damage. Oxidative stress results in high levels of lipid peroxidation product (MDA) and DNA-damage product (8$\mathrm{OHdG})[1,3]$. Cell apoptosis, reduction in levels of endogenous antioxidants and increased production of lipid peroxidation and DNA damage products contribute to oxidative stress in cryptorchidism rats, and ultimately to infertility $[9,20,24]$.

In this study, the activities of GPx, catalase and SOD in rat testis were significantly decreased in ULC group, relative to control group, while the levels of MDA and 8-OHdG were markedly increased in ULC group, when compared with control group. However, treatment with ethanol extract of Cuscuta chinensis seeds significantly and dose-dependently increased the activities of the antioxidant enzymes, but reduced the levels of MDA and 8-OHdG. These results indicate that the extract may possess good antioxidant and anti-apoptotic effects, and are in agreement with those of previous studies [12]. The results of a previous study showed that treatment with a herbal formula rich in Cuscuta chinensis $(\mathrm{KH}-$ 204) significantly enhanced antioxidant levels, while decreasing the level of 8-OHdG in rats with cryptorchidism [14]. The activities of caspase-3 and caspase-9 were significantly higher in ULC group than in control group, but they were significantly reduced by extract treatment.

Cryptorchidism results in over-production of free radicals which trigger oxidative damage in testis via activation of apoptotic cascade. The oxidative stress disrupts mitochondrial membrane, leading to the release of cytochrome $c$ and subsequent activation of the caspase system (especially caspase-3 and caspase-9) [15]. Treatment of ULC rats with graded doses of ethanol extract of Cuscuta chinensis seeds significantly decreased the activities of caspase- 3 and caspase- 9 , an indication that the extract may possess antiapoptotic effect. Studies have shown that polysaccharides isolated from the seeds of Cussuta chinensis significantly decreased the 
intracellular $\mathrm{Ca}^{2+}$ level and regulated the release of caspases in a rat model of ULC [25].

The Nrf2/HO-1 signaling pathway is a major signaling pathway that regulates redox homeostasis and cell integrity. Under physiological conditions, Nrf2 is localized in the cytosol bound to Keap1 in an inactive form. On stimulation by oxidative stress or pathological conditions, Nrf2 becomes activated (dissociates from Keap1), translocates to the nucleus and becomes bound to antioxidant response element (ARE). While in the nucleus, it regulates the expression of various antioxidant and detoxification enzyme genes such as $\mathrm{HO}-1$, glutathione, SOD, Y-glutamylcysteine synthetase (yGCS), catalase, and NADPH:quinone oxidoreductase 1 (NQO-1), thereby protecting the cells from damage [26]. The involvement of Nrf2/HO-1 signaling pathway in infertility has been reported [6]. In this study, the protein expressions of Nrf2 and $\mathrm{HO}-1$ were significantly downregulated in ULC group, relative to control group, but they were markedly upregulated after treatment with the extract.

Elevated level of reactive oxygen species (ROS) reduces the antioxidant capacity of cells and negatively regulates Nrf2/HO-1 signaling pathway. The results obtained in this study indicate that the fertility-enhancing effect of ethanol extract of Cussuta chinensis seeds may be positively regulated by $\mathrm{Nrf} 2 / \mathrm{HO}-1$ signaling pathway. The results of a previous study showed that treatment with herbal formula rich in Cuscuta chinensis (KH-204) significantly upregulated the protein expressions of Nrf2 and HO-1 in both cell and animal model [26].

The results of histopathological examination provided supportive evidence for the biochemical data. Cross section of testicular tissues of rats in ULC group showed narrowed and thickened seminiferous tubules (disrupted spermatogonia) characterized by increased apoptotic bodies (increased number of necrotic Sertoli and Leydig cells). Testicular tissues of rats treated with 100 $\mathrm{mg}$ extract $/ \mathrm{kg}$ bwt showed less thickening of seminiferous tubules and reduced number of apoptotic bodies. There were few damaged or necrotic Sertoli and Leydig cells and complete absence of thickening of seminiferous tubules in testicular tissues of rats treated with $200 \mathrm{mg}$ extract/kg bwt. These results are in agreement with those reported previously [27]. The aphrodisiac effect was better in $200 \mathrm{mg}$ extract/kg group than in $100 \mathrm{mg} / \mathrm{kg}$ group. The major limitation of this study is failure to investigate other necrotic parameters and expression levels of pro- and anti-apoptotic markers (bax, bcl-2 and bid).

\section{CONCLUSION}

The ethanol extract of Cuscuta chinensis seeds effectively mitigates cryptorchidism in rats via mechanisms involving the regulation of Nrf2/HO1 signaling pathway, and inhibition of apoptosis and oxidative stress. Thus, the extract can potentially be developed as anti-infertility therapy.

\section{DECLARATIONS}

\section{Acknowledgement}

This study was supported by the Scientific Research Project of the Wuhan Municipal Committee of Health Keys (no. WX19D30).

\section{Conflict of interest}

No conflict of interest is associated with this work.

\section{Contribution of authors}

We declare that this work was done by the authors named in this article and all liabilities pertaining to claims relating to the content of this article will be borne by the authors. Jiao Shu, Li $\mathrm{Li}$ and Dandan Zhang designed and executed this study. Hui Yu and Dandan Zhang helped in statistical analysis. HuiYu and Li Li drafted this manuscript. Jiao Shu helped in histological analysis.

\section{Open Access}

This is an Open Access article that uses a funding model which does not charge readers or their institutions for access and distributed under the terms of the Creative Commons Attribution License (http://creativecommons.org/licenses/by/ 4.0) and the Budapest Open Access Initiative (http://www.budapestopenaccessinitiative.org/rea d), which permit unrestricted use, distribution, and reproduction in any medium, provided the original work is properly credited.

\section{REFERENCES}

1. Mahdavi R, Heshmati J, Namazi N. Effects of black seeds (Nigella sativa) on male infertility: A systematic review. J Herbal Med 2015; 5: 133-139.

2. Meng Q, Ren A, Zhang L, Liu J, Li Z, Yang Y, Li R, Ma L. Incidence of infertility and risk factors of impaired 
fecundity among newly married couples in a Chinese population. Rep Biomed Online 2015; 30(1): 92-100.

3. Mahat RK, Kumar S, Arora M, Bhale DV, Mehta R, Batra J. Role of oxidative stress and antioxidants in male infertility. Int J Health Sci Res (IJHSR) 2015; 5: 324-333.

4. Kefer JC, Agarwal A, Sabanegh E. Role of antioxidants in the treatment of male infertility. Int J Urol 2009; 16: 449457.

5. Babaei H, Azari O, Kheirandish R, Abshenas J, Mohammadi $N$. Zinc therapy improves deleterious effects of experimental unilateral cryptorchidism: histopathological evaluation of testes. Iran J Vet Surg 2010; 5(1-2): 77-88.

6. Bae WJ, Ha U, Choi JB, Kim KS, Kim SJ, Cho HJ, Hong SH, Lee JY, Wang Z, Hwang SY, Kim SW. Protective effect of decursin extracted from Angelica gigas in male infertility via Nrf2/HO-1 signaling pathway. Oxid Med Cell Longev 2016; 2016.

7. Afolabi AO, Alagbonsi IA, Oyebanji TA. Beneficial effects of ethanol extract of Zingiber officinale (ginger) rhizome on epididymal sperm and plasma oxidative stress parameters in experimentally cryptorchid rats. Ann Res Rev Biol 2014:1448-60.

8. Brezina PR, Yunus FN, Zhao Y. Effects of pharmaceutical medications on male fertility. $J$ Rep Infert 2012; 13(1): 3.

9. Tremellen $K$. Oxidative stress and male infertility: $A$ clinical perspective. Hum. Reprod Update 2008; 14: 243-258.

10. Kang SY, Jung HW, Lee MY, Lee HW, Chae SW, Park $Y K$. Effect of the semen extract of Cuscuta chinensis on inflammatory responses in LPS-stimulated BV-2 microglia. Chinese journal of natural medicines. 2014; 12(8): 573-581.

11. Donnapee S, Li J, Yang X, Ge AH, Donkor PO, Gao XM, Chang YX. Cuscuta chinensis Lam.: a systematic review on ethnopharmacology, phytochemistry and pharmacology of an important traditional herbal medicine. J Ethnopharmacol 2014; 157: 292-308.

12. Liao JC, Chang WT, Lee MS, Chiu YJ, Chao WK, Lin YC, Lin $M K$, Peng WH. Antinociceptive and antiinflammatory activities of Cuscuta chinensis seeds in mice. Am J Chin Med 2014; 42(01): 223-242.

13. Hou DY, Li TC, Yu B. Comparative study of volatile oil on Cuscuta 2 species. J Chin Mass Spectromet Soc 2003; 24: 343-345.

14. Bae WJ, Ha US, Kim KS, Kim SJ, Cho HJ, Hong SH, Lee JY, Wang Z, Hwang SY, Kim SW. Effects of KH-204 on the expression of heat shock protein 70 and germ cell apoptosis in infertility rat models. BMC Complement Alternat Med 2014; 14: 367.

15. Yang J, Wang $Y$, Bao $Y$, Guo J. The total flavones from Semen cuscutae reverse the reduction of testosterone level and the expression of androgen receptor gene in kidney-yang deficient mice. J Ethnopharmacol 2008; 119: 166-171.

16. Cui $H$, Dong $P$, Chen B. Effect of total flavonoids of Cuscuta chinensis Lam. (Convolvulaceae) on oxidative stress injury in mouse testis and epididymis, and on serum levels of reproductive hormones in oligoasthenospermia mice model. Trop J Pharma Res 2019; 18(6): 1253-1258.

17. Yen FL, Wu TH, Lin LT, Cham TM, Lin CC. Concordance between antioxidant activities and flavonol contents in different extracts and fractions of Cuscuta chinensis. Food Chem 2008; 108: 455-462.

18. Julkunen-Tiitto R. Phenolic constituents in the leaves of northern willows: methods for the analysis of certain phenolics. J Agri Food Chem 1985; 33: 213-217.

19. Wang CK, Hwang LS. Analysis of the phenolic compounds in betel quid. J Chin Agri Chem Soc 1993; 31: 623-632.

20. Tsounapi $P$, Honda $M$, Dimitriadis F, Shimizu S, Iguchi $M$, Imanishi M, Matsunaga S, Kawamoto B, Hikita K, Muraoka K, Sejima T. 176 Unilateral cryptorchidism induces testicular cells' DNA oxidative damage and apoptosis bilaterally in the rat; the effects of antioxidants administration. European Urology Supplements. 2015; 2(14): e176.

21. Sonmez MG, Türk A, Yüce. The effect of ascorbic acid supplementation on sperm quality, lipid peroxidation and testosterone levels of male wistar rats. Theriogenol 2005; 63(7): 2063-2072.

22. Benson RC Jr, Beard CM, Kelalis PP, Kurland LT. Malignant potential of the cryptorchid testis. Mayo Clin Proc. 1991; 66: 372-378.

23. Wang J, Wang M, Ou Y, Wu Q. Effects of flavonoids from semen Cuscutae on changes of beta-EP in hypothalamuses and $\mathrm{FSH}$ and $\mathrm{LH}$ in anterior pituitaries in female rats exposed to psychologic stress. Zhong yao cai Zhongyaocai. J Chin Med Mat 2002; 25: 886-888.

24. Akbari A, Jelodar GA. The effect of oxidative stress and antioxidants on men fertility. Zahedan $\mathrm{J}$ Res Med Sci 2013; 15: 1-7.

25. Sun SL, Guo L, Ren YC, Wang B, Li RH, Qi YS, Yu H, Chang ND, Li MH, Peng HS. Anti-apoptosis effect of polysaccharide isolated from the seeds of Cuscuta chinensis Lam on cardiomyocytes in aging rats. Mol Biol Rep 2014; 41(9): 6117-24.

26. Bae WJ, Zhu GQ, Choi SW, Jeong HC, Bashraheel F, Kim KS, Kim SJ, Cho HJ, Ha U, Hong SH, Lee JY. Antioxidant and antifibrotic effect of a herbal formulation in vitro and in the experimental andropause via Nrf2/HO1 signaling pathway. Oxi Med Cell Longiv 2017; 2017.

27. Fio D, Olalekan OO, Azu OO, Okoko II. L-arginine augments oxidative stress in cryptorchid testes of adult Sprague-Dawley rats. JMMS 2011; 2(4): 777-782. 